\title{
Dewey's Notion of Imagination in Philosophy for Children
}

\author{
Jennifer B. Bleazby
}

\section{Abstract}

The imagination has traditionally been associated with unreality and is commonly thought to be the antithesis of reason. This is a notion of imagination that can be found in Plato's writing and has influenced modern Western epistemology and educational ideals. As such, traditional schooling, which has focused on the cultivation of reason and the accumulation of facts, has devalued the imagination and frequently encouraged children to transcend their imaginative natures. In this paper, I draw on the work of John Dewey to explain how imagination is not opposed to thinking. Nor is the imagination a distinct form of thinking. I argue that it is actually integral to all thinking and, as such, is essential for living a meaningful life. I then argue that one of Philosophy for Children's strengths is that its pedagogy and curriculum content are ideal for facilitating this Deweyian ideal of imagination and, thus, reflective thinking and meaningful learning.

Kieran Egan states that imagination "is a concept that has come down to us with a history of suspicion and mistrust" (2007, p. 4). Like experience and the emotions, the imagination is frequently thought to be an obstacle to reason. While reason is conceived of as an abstract, objective and rule-governed method of delivering absolute truths, the imagination is considered "unconstrained, arbitrary, and fanciful," as well as "particular, subjective, and idiosyncratic" (Jo 2002, p. 39). This negative view of the imagination can be traced back at least as far as Plato, and it is still evident in contemporary educational ideas and practices. Dominant approaches to schooling 
emphasize the accumulation of facts and the cultivation of reasoning rather than the development of imagination (Nussbaum, 2010; Egan \& Judson, 2009; Egan, 2007; Haralambous, Fitzgerald, \& Nielsen, 2007; Kennedy 2006; Greene 1995; Dewey 1997). At best, the imagination is conventionally seen as a valuable capacity that is entirely distinct from reason and is primarily cultivated in "the arts."

In this article I draw on John Dewey's theory of inquiry to argue that the imagination is not an obstacle to reason, nor merely a valuable and distinct capacity, but rather an integral element of all thinking. I refer to this Deweyan notion of imagination as the "intelligent imagination" to distinguish it from other accounts, as well as from fantasy and reverie. I argue that all schooling must cultivate the imagination as a basic, interdisciplinary capability and that integrating philosophy into the curriculum-particularly the Philosophy for Children approach to teaching philosophy - is one way that schools may make some progress towards achieving this goal. Originally developed by Matthew Lipman and Ann Margaret Sharp, Philosophy for Children (P4C) integrates the methods and content of philosophy and the pragmatist idea of a Community of Inquiry in order to teach critical, creative, caring, and communal thinking skills, as well as the attitudes necessary for life in a democracy. A typical P4C class involves the shared reading of a narrative, containing philosophically puzzling ideas, followed by a classroom dialogue initiated by student questions and responses to the text. Through formulating questions, articulating problems, defining concepts, constructing solutions, expressing opinions, providing reasons and evidence, constructing criteria, searching for counter examples and evaluating arguments and ideas, students aim to reconstruct philosophical problems and, in so doing, make sense of their world. This process necessitates, as well as scaffolds, the development of the intelligent imagination.

\section{The Platonic View of the Imagination}

Considering the significant influence Plato's ideas have had on Western notions of truth, knowledge, reason, reality, and education, it is not surprising that some of his negative comments about the imagination are reflected in contemporary approaches to schooling. For Plato, reason and philosophy give us access to reality and absolute truth, while the imagination and art are associated with sense experience, the emotions and unreality. Plato conceives of ultimate reality as the nonphysical, transcendental realm of the Forms, which are abstract concepts. The physical world of sense experience is not genuine reality, but merely a copy. Images are copies of the physical world, filtered through the interests, emotions and restricted embodied perspectives of those who create them (Plato, 1998, para. 598b). Thus, for Plato, what is imagined is three degrees away from reality. To explain this idea Plato provides the example of a bed. There is the Form of bed, which is an abstract idea or concept. This is the real bed. Then there are the physical beds that we sleep on, created by craftsman to partake in the Form of bed. Thus, these concrete beds are only copies of the Form of bed. Then finally there are images of beds. These images, 
such as paintings of beds, are mere copies of concrete beds. That is, they are copies of copies of reality (Plato, 1998, para. 597b-597e). This conceptualization applies to the images in dreams, poetry, myths, music, and rhetoric, as much as to the images created by painters and sculptures.

Plato's concern with the imagination is not just that images are unreal, but that we may mistake the images for reality, like the prisoners in Plato's cave who believe the shadows on the wall are real and, consequently, never learn the truth about their world. Even when an escaped and enlightened prisoner returns to inform the other prisoners that reality is actually outside the cave, the prisoners are mostly unable to accept that there could be anything more real than the shadows on the wall (Plato, 1998, para, 514a-518b). This is particularly concerning for Plato, given the imagination's capacity to construct very seductive images of reality, just as artists often represent the world in a idealized or beautified manner. This is why Plato associates painting, poetry, sculpture, and music with the rhetoric practiced by the sophists, which he describes as an immoral activity aimed at deception. An individual who is deluded about her own nature and abilities and the world around her is unlikely to live a happy life or be a productive member of society. Such a person is likely to ignore "real" problems and potential dangers and instead devote herself to the pursuit of unachievable ends.

While Plato is more frequently associated with this negative view of the imagination (e.g., Egan, 2007; Fesmire, 2003), he does not entirely condemn the imagination or the arts (e.g., Bundy, 1922; Thayer, 1977). The imagination is included on Plato's divided line, which represents four stages of human understanding (Plato, 1998, para. 509c-511e). The line is first divided into two parts, with one part representing the visible realm of material objects, and the other representing the intelligible realm of the Forms. The visible realm is further divided into two parts, with one part representing opinion or belief and the other representing imagination and conjecture. While the imagination is included in the stages of human understanding, it is still associated with the subjective senses, and thus relegated to a status lower than mere opinion. However, Bundy argues that the section of the line representing the intelligible realm also includes imagination (1922, pp. 368-369). The intelligible realm is also divided into two parts; the first part is called understanding while the other, superior part, is called dialectic. In the stage called "understanding" one uses images of physical objects in order to understand the Form of the thing being contemplated. For example, a mathematician will use a mental image of a triangular shaped object in order to theorize about the Form of triangularity. This stage seems to correspond with science in that it involves hypothesizing, generalizing and theorizing about the material world. Thus, Plato may actually suggest two notions of the imagination, one perceptual and the other intelligible (Bundy, 1922, pp. 368-369). However, even on this reading, the imagination is still distinct from, and subordinate to, pure reason or dialectic, the highest stage of understanding, which is not dependent on either perception or imagination. As such, imagination also remains a potential obstacle to reason. 
Since Plato believed the imagination could be a powerful force that leads us astray, he also thought education should help individuals overcome or control their imaginations. However, in accordance with his divided line metaphor, Plato suggested that the imagination, controlled by reason, had some educational value. Carefully created stories and music played an important role in Plato's theory of primary education (1998, para. 376e-392e, 401b-403c). The later years of schooling, which were to be limited to those who would perform the more important protective and leadership roles in society, were to be largely devoted to mathematics and philosophy in order to develop the faculty of reason, which remained the ultimate goal of education.

The notion of the imagination as the potentially seductive antithesis of reason is reflected in many modern beliefs about the nature of reason, knowledge, and learning. While not all philosophers have put forward negative views of the imagination, they have largely tended to ignore, sideline, or be wary of the imagination. As Egan (2007) explains, even those who suggest that the imagination plays some fundamental role in human understanding have expressed uncertainty about its nature and value (e.g., Hume and Kant). As such, the imagination is predominantly considered to be mysterious and potentially problematic, if not outright dangerous.

\section{Dewey's Theory of the Imagination}

Dewey is one of the few philosophers who unambiguously emphasizes the fundamental interrelatedness of the imagination and thinking. However, as Steven Fesmire points out, Dewey's account of the imagination has been largely ignored, even by Dewey scholars (2003, p. 64). This is probably because his comments on the imagination are scattered throughout his immense body of work rather than explained in one comprehensive piece of writing. Dewey describes several roles that the imagination plays in the process of inquiry: conceiving of alternatives to problematic situations or "ends-in-view"; suggesting means to reach those ends; evaluating those means through considering their possible consequences if applied (what Dewey calls reasoning); making use of past experience; fostering sympathetic or moral imagination; and enabling dialogue and communal inquiry. This section will provide an explanation of each of these functions of the intelligent imagination.

Dewey rejects the Platonic notion of an entirely nonphysical, abstract realm of ideas. Thus, thinking is not conceived of as some disembodied, transcendental method of acquiring absolute truths. For Dewey, thinking is reflective experience. It is the reconstruction of problematic, unsettled, or fragmented experiences into coherent, meaningful situations. Problematic experiences occur when our habitual way of interacting with our environment becomes ineffective in satisfying our

needs and interests. Consequently, thinking emerges as the means to readjusting and coordinating ourselves and our environment so that we can survive and grow. The imagination plays a fundamental role because it enables us to go beyond actual experience and imagine situations as other than they are. Thus, we are able to 
imagine fragmented, incomplete situations as coherent, meaningful wholes. Without this capacity, we would simply have to accept the status quo and there would be no need for thinking. Although he is also referring to fancy and reverie, Dewey suggests the problem solving function of the imagination in the following passage:

The things most emphasized in imagination as it reshapes experience are things which are absent in reality. In the degree in which life is placid and easy, imagination is sluggish and bovine. In the degree in which life is uneasy and troubled, fancy is stirred to frame pictures of a contrary state of things. By reading the characteristic features of any man's castles in the air you can make a shrewd guess as to his underlying desires which are frustrated. What is difficulty and disappointment in real life becomes conspicuous achievement and triumph in reverie; what is negative in fact will be positive in the image drawn by fancy; what is vexation in conduct will be compensated for in high relief in idealizing imagination. (Dewey, 2004b, p. 60)

The imagined possibilities for the problematic situation are the desired "ends in view" that give inquiry a goal, purpose, framework, and direction. Through inquiry we consider means to actualize these imagined possibilities. These means are also imagined because they are yet to be actualized. They suggest future possible action. Until these means have actually reconstructed the problematic situation as intended, they are only tentative solutions, or what Dewey calls "ideas" (Dewey, 2004a, p. 152; 1997, p. 75). "Hypothesizing," "speculating," "conjecturing," and "suggesting" are some of the other words that Dewey uses to describe this imaginative process of creating possible means for reconstructing experience. When these ideas have been actualized they are called facts, truths, knowledge, or warranted assertions.

For Dewey, ideas and suggestions are not imaginative just because they go beyond what is immediately given in experience. An imaginative idea is one that we expect to be realized (1997, p. 7). Dewey distinguishes between imagination on the one hand and fancy or reverie on the other. The latter are concerned with thoughts that have little or no possibility of realization and are thus unlikely to assist in reconstructing experience (Dewey, 1958a, pp. 267-269, 273; 1967, pp. 170171). He states that, unlike the imagination, the thoughts entertained in reverie do not "aim at knowledge, at belief about facts or in truths" (Dewey, 1997, p. 3). Robin Barrow describes a similar notion of imagination, stating that imaginative ideas are not just original but also effective in that they are "conducive to a good solution to, or resolution of, the task or problem at hand" (1988, p. 85). When Plato talks about the imagination leading us away from reality and truth, he seems to have in mind what Dewey calls fancy or reverie. Dewey would probably agree that reverie has this potential but, unlike Plato, he clearly distinguishes between reverie and the imagination. The primary function of the later, for Dewey, is actually to help us understand and transform reality. As Dewey states, "the healthy imagination deals not with the unreal, but with the mental realization of what is suggested. Its 
exercise is not a flight into the purely fanciful and ideal, but a method of expanding and filling in what is real" (1997, pp. 166).

Dewey's notion of intelligent imagination is somewhat similar to the capacity represented on the third section of Plato's divided line, which Plato calls "understanding." As we have seen, Plato's notion of understanding resembles scientific inquiry in that it involves hypothesizing about the physical world. This was the other stage of Plato's epistemology that Bundy thought involved imagination (1922, pp. 368-369). This suggests that Dewey and Plato had a similar understanding of at least one of the functions of imagination-conjecturing, hypothesizing, making suggestions about the physical world. However, their different metaphysical and epistemological beliefs lead them to disagree about the value of this notion of imagination. Since he rejects the notion of a nonphysical realm, Dewey also rejects the notion of pure reason represented by the fourth section of Plato's divided line. For Dewey, there is no type of thinking or means of human understanding that supersedes the imagination and experience. Dewey would believe that the processes represented in the first, second, and third sections of the divided line were the only possible means of human understanding. (Dewey would also disagree with the way Plato divides these processes up and defines them). Since Dewey believed that all modes of human understanding were experiential and imaginative, the imagination occupies a much more fundamental, and less ambiguous, position in his epistemology than it does it Plato's idealist theory.

While Dewey rejects Plato's notion of transcendental reason, he believes that a different notion of reasoning plays an important role in inquiry. This notion of reason is also experiential and imaginative. Dewey specifically reserves the term "reasoning" for the process of critically evaluating the means that are suggested for reconstructing experience. We don't simply enact every means suggested for achieving our ends in view. This would be inefficient and even dangerous. We must carefully evaluate all suggested means prior to acting on them. Dewey distinguishes between suggestions and conjectures on the one hand, which are more immediate and vague, and ideas on the other, which have been subject to careful critical examination and, as such, are more likely to be effective and unproblematic if applied. According to Dewey, we critically examine suggestions and conjectures by inferring what consequences would likely follow from them if they were actualized. It is this process of making inferences that Dewey calls reasoning (1997, pp. 75-76; 1938, pp. 110-112). Thus, reasoning involves considering whether a suggestion is likely to reconstruct the problematic situation as intended and if it could result in any undesirable consequences. A useful example of the reasoning process is provided by Dewey. A man returns home to find his house ransacked, and two possible explanations are immediately suggested: either he has been burgled or his children have made a mess, as they often do. Before acting on either suggestion, he considers the implications of having been burgled as opposed to the children having made a mess. One implication is that if he has been burgled, certain valuable 
items will be missing. This possibility suggests further observations to be made, namely that he check to see if the items are in fact missing. From the fact that they are missing, the man infers that the suggestion that he has been burgled is more likely true (Dewey, 1997, pp. 82-83). Reasoning is also an imaginative process because it involves imagining the consequences of suggestions if they were applied. These consequences go beyond experience. This is why Dewey states that "inference is always an invasion of the unknown, a leap from the known" (2004a, p. 152). Even if we don't accept Dewey's stipulative definition of reasoning, it seems obvious that all reasoning is an imaginative activity because all reasoning involves going beyond immediate experience so as to make various connections.

The imagination doesn't just enable us to bring to mind future possibilities; it also enables us to make use of past experiences (Dewey, 1967, p. 169; Dewey, 1991, p. 106). Our past experiences are also essential components of inquiry because they suggest alternative possibilities, as well as means for bringing about these possibilities. If a problematic situation is completely unfamiliar to us, if we have no relevant prior knowledge to help us make sense of it, we will be unable to meaningfully reconstruct it. For example, Dewey's burglary victim draws on his prior knowledge of burglaries to infer that the hypothesis that he has been burgled is likely to be accurate (Dewey 1958a, p. 272).

The imagination also enables moral reasoning, which, for Dewey, is another essential attribute of all thinking. Ethics is one area where the imagination has gained significant attention because of its obvious connection to empathy (e.g., Nussbaum, 2010; Kirkman, 2009; Glover, 1999; Greene, 1995; Johnson, 1993). Empathy involves imagining alternative perspectives, how other people might feel and what their desires, needs and interests may be. The empathetic or moral imagination is particularly important for understanding, and interacting with, those most different from us. It is essential for communal life because it enables an awareness of other individuals, including past and future individuals, even in their physical absence. Such awareness gives rise to thinking and conduct that promotes social, not just personal, freedom, growth, and happiness. For Dewey, the empathetic imagination is actually necessary for all inquiry. There are two reasons for this. First, our environment is necessarily social and cultural. Since inquiry is the process of effectively interacting with our environment, all inquiry must take into account the interests, aims, and actions of other people. Thus, Dewey believed that communal inquiry was always superior to individual inquiry because it leads to knowledge that integrates diverse perspectives and that has been tested in a wider field of experience. Such knowledge is more objective and more likely to be effective (Dewey, 1938, pp. 45-46). Second, like Lev Vygotsky (1978), Dewey argued that thinking has its origins in dialogue. He described thinking as the internalization of the processes that characterize social interaction, stating that "soliloquy is the product and reflex of converse with others; social communication not an effect of soliloquy. If we had not talked with others and they with us, we should never talk 
to and with ourselves ... Thus mind emerges." (1958b, p. 170). When we think, we criticize and defend our own ideas the way we would if we were engaged in dialogue with a critical other. If communal inquiry is always the superior mode of thinking and thinking itself originates in social interaction, the empathetic imagination is essential for all thinking.

Unlike Plato, then, Dewey does not conceive of the imagination as something opposed to thinking, reasoning, knowledge, or reality. According to Dewey, the imagination enables us not only to understand reality, but also transform it so that it is more conducive to individual and social growth and flourishing. The imagination also enables us to imagine ourselves as other than we currently are and thus to transform ourselves so that we can interact with our environment in a more harmonious manner. Consequently, this notion of imagination is also essential for autonomy and personal happiness.

\section{The Imagination in Traditional Education}

Traditional schooling tends to discourage the intelligent imagination by presenting students with facts as if they are settled, unproblematic, and ready to be memorized. There is an underlying assumption that the aim of schooling is to help students adapt to a fixed environment and that growth and education has some final end point. As David Kennedy explains, this results in a "failure to develop initiative in coping with novel situations" and an "undue emphasis upon drill and other devices which secure automatic skill at the expense of personal perception" (2006). As we have seen, the intelligent imagination is initiated by the need to clarify perplexities, control contingencies, and reconstruct oneself and one's environment. If everything appears certain, absolute, unproblematic, and complete, then there is no reason for students to imagine things as other than they are. As Dewey explains, "The feeling that instruction in 'facts, facts' produces a narrow Gradgrind is justified not because facts in themselves are limiting, but because facts are dealt out as such hard and fast ready-made articles as to leave no room to imagination" (1997, pp. 223-224).

While this type of schooling is often considered "old-fashioned" and has been extensively criticized, it is still widely practiced and defended. For example, it is reflected in the "return to basics" and "core knowledge" ideologies. These ideologies emphasize all students learning the same prescribed content and skills, with a focus on students accumulating facts (e.g., Quirk, 2005; Hirsch, 1987). Maxine Greene argues that such traditional notions of schooling are seen as antidotes to the seemingly unstable and unpredictable nature of modern life, which is characterized by rapid technological advancements, easy access to masses of often contradictory information, and increasingly globalized and multicultural communities. The stability of basic, core knowledge and skills is seen as more desirable than fostering the imagination, which only seems to encourage further instability and complexity: "In response to school changes, many parents yearn not merely for the predictable but also for the assurances that used to accompany children's mastery 
of the basics. Talk of tapping hitherto untapped possibilities and exploring unexplored alternatives serves to intensify the unease of those who want perhaps most of all to recover the simpler world of a time long past" (Greene, 1995, p. 18). Kennedy has a similar perspective on traditional schooling, stating "there are induced lack of interest in the novel, aversion to progress, and dread of the uncertain and the unknown" (2006, para. 18).

Traditional educational ideas are also reflected in what John McNeil (2009) calls the systematic approach to curriculum. This approach stresses efficiency and accountability through government mandated curriculum; the rigid alignment of stated learning outcomes with curriculum content, pedagogy, and assessment, and it usually involves high stakes testing. The systematic approach is currently being applied in many Western nations, including Australia, the United States, and England, and it has also been widely criticized (see McNeil, 2009; Lingard, 2009; Berliner, 2009; Kelly, 2009; Nussbaum, 2010). It tends to result in schooling that is teacher centered, content heavy, and predictable, with many teachers simply "teaching to the test." Complex capacities like critical thinking and imagination are sidelined as the curriculum is narrowed to focus on skills and content that can be easily assessed in standardized tests, such as basic literacy and numeracy skills and the recall of facts. The most efficient way to prepare students for such tests is through rote learning and drill. Egan argues that the current dominance of the systematic approach to schooling is inimical to fostering the imagination:

In general, imagination has not fared well as might have been expected in educational writings about the design of curricula, teaching methods, and studies of student's learning. It seems to have become sidelined by agendas that are more urgent, that seek specific social objectives from teaching, and that focus on efficiency and accountability. From the perspectives of those who have encouraged and directed this general movement in public education, imagination seems something of a frill; containing value, no doubt, but a value left to the "arts" rather than to the more central purposes of a public system that is paid for by people who often have objectives for their investment that are more specific. (2007, pp. 3-4)

Not only is the imagination often "left to the arts," the arts themselves are sidelined. David Berliner has argued that this approach to schooling leads to a decrease in the amount of time devoted to the arts so that teachers can focus on teaching the skills and knowledge that are assessed on high stakes tests (2009; see also Nussbaum, 2010). The time demands of the systematic model additionally discourages the teacher's imagination, which in turn reduces the likelihood of students engaging in imaginative learning experiences. One teacher quoted by Michael Apple stated, "I just want to get this done: I don't have time to be creative or imaginative" (2009, p. 206). As Apple explains, "we should not blame the teacher here. In mathematics, for example, teachers typically had to spend half the allotted time correcting and recording the worksheets the students completed each day" (2009, p. 206). 
As Egan states above, when schools do aim to foster the imagination, it is often through the arts. Greene argues that the arts have a unique ability to foster the imagination because works of art go beyond immediate experience and evoke alternative and multiple versions of reality:

It is because I believe that encounters with the arts can awaken us to alternative possibilities of existing, of being human, of relating to-others, of being other, that I argue for their centrality in curriculum. I believe they can open new perspectives on what is assumed to be 'reality,' that they can defamiliarize what has become so familiar it has stopped us from asking questions or protesting or taking —action to repair. (1993, p. 214)

While I agree that the arts do have a unique ability to foster the imagination and that they should be given greater importance in the curriculum, the problem with focusing narrowly on the arts as a means to fostering the imagination is that this can reinforce the view that the imagination is distinct from reason and that is not relevant to subjects like maths and science. We don't want the imagination to be seen as something peculiar to the arts. Nor do we want the arts to be seen as opposed to reason because they emphasize the imagination. As Nussbaum argues, "[students] need to see an imaginative dimension in all their interactions, and to see works of art as just one domain in which imagination is cultivated" (2010, p. 103). Dewey believed that all academic disciplines "are full of matters that must be imaginatively realized if they are realized at all" (Dewey, 1997, pp. 223-224). Schools must help students see that all good thinking, whether it be in science, art, or physical education, is imaginative. Philosophy may assist schools in achieving this goal.

\section{Fostering the Imagination through Philosophy in Schools}

Like the arts, philosophy has a special ability to incite the intelligent imagination. Philosophy problematizes the taken for granted aspects of everyday experience and, as such, it provokes the consideration of alternative possible ways of being in the world. Philosophy involves questioning, wondering, criticizing, and going beneath the surface of what is immediately given. Unlike the closed questioning that characterizes traditional schooling, philosophical questions don't presuppose one correct, fixed answer. Philosophical questions are often open ended and may have many answers which are likely to be contentious, open to criticism, and lead to further questions. Thus, philosophical questions open up a space for the imaginative consideration of alternative possibilities. Philosophy is also unique in that it draws out the problematic, contentious, and imaginative aspects of other disciplines. Other school subjects often take it for granted that truth, freewill, justice, democracy, and beauty exist, and they even make uncritical assumptions about what such concepts mean. In contrast, philosophy assumes that such concepts are contentious, and so much philosophical inquiry is devoted to exploring and defining them. Because such concepts are so fundamental to all our experiences and understandings, philo- 
sophical inquiry can provoke us to imaginatively reflect on every aspect of our lives. Teachers of other subjects frequently told me, a high school philosophy teacher, that my philosophy students were constantly bringing up philosophical issues in their classes. While some teachers appreciated the depth of understanding and critical attitude that these students were displaying, some also seemed to find it frustrating because they wanted the students to stop complicating the content so that they could move through the curriculum more efficiently. Philosophy's introduction into the curriculum may help foster the imagination in all subject areas and disrupt schooling focused on the efficient accumulation of facts.

The seemingly abstract and often idealistic nature of philosophical subject matter also excites the imagination. Philosophers have relied heavily upon imaginative devices like metaphors, similes, analogies, allegories, hypotheticals, thought experiments, and fictional narratives as a means of exploring and clarifying philosophical problems and ideas. Such devices are useful for clarifying and reinforcing the relationship between the seemingly abstract problems and ideas of philosophy and our concrete experiences. One well known example of this is Derek Parfit's teletransporter. Parfit asks us to imagine using a teletransporter to travel to Mars at the speed of light as a way of getting us to think about the nature of personal identity:

When I press the button, I shall lose consciousness, and then wake up at what seems a moment later. In fact I shall have been unconscious for what seems like about an hour. The scanner here on earth will destroy my brain and body, while recording the exact states of all my cells. It will then transmit the information by radio. Travelling at the speed of light, the message will take three minutes to reach the Replicator on Mars. This will then create, out of new matter, a brain and body exactly like mine. It will be in this body that I shall wake up. (Parfit, 1984, p. 199)

This scenario prompts us to consider whether the replica would be identical to the person who got in the teletransporter or if it would be a new person. Such fictional scenarios can help us draw out the implications and significance of complex metaphysical problems and theories for our everyday lives. Metaphorical thinking plays an equally important role in philosophy. As we have seen, Plato himself famously utilized metaphorical thinking. Plato's most famous metaphor, the Allegory of the Cave, explicates his complex idealist theory of reality and knowledge, while emphasizing the fundamental implications this theory has for our everyday experiences. Furthermore, many philosophical theories are normative rather than descriptive. As such, they outline ideals that may not currently exist. When there are no concrete examples of normative ideas, philosophers often rely on metaphorical thinking, stories, or hypotheticals to explain and evaluate such ideas (e.g., Williams, 1973). It is for such reasons that Parfit states that these imaginary devices can help us clarify and develop our understanding of reality (1984, p. 200). Lipman's Philosophy for Children curriculum also relies upon fictional narratives to embed philosophical 
ideas in stories relevant to the lives of young people. These stories prompt philosophical inquiry that involves students unpacking and creating fictional scenarios, hypotheticals, and metaphors as a means of clarifying perplexities and making sense of their world (see Hamrick, 1989).

The close relationship between philosophy and the imagination is also implied by the claim that children, who are thought to be naturally imaginative, have a natural propensity for philosophy. It is argued that children wonder about the seemingly mundane, ask questions of a philosophical nature, and constantly search for meaningfulness (Lamb, 2002; Matthews, 1980). The child's tendency for wonderment and curiosity seems to result from the fact that they are frequently having new experiences but lack the concepts that would help them make sense of those experiences. Their thinking has also not been so moulded by dominant cultural beliefs and values. The constant stream of new and confusing experiences provokes philosophical wonderment, as well as the search for alternative possibilities and explanations. It is not surprising that Splitter and Sharp believe their imaginative tendency may give children an advantage when it comes to philosophical thinking: "When it comes to that aspect of thinking, which is concerned with meaning and understanding-with making sense of something which presents itself as puzzling or intriguing - the young child's ability to imagine new possibilities and think creatively may be even more valuable than her mature counterpart's greater experience and linguistic sophistication" (Splitter and Sharp 1995, p. 97).

Thus, integrating philosophy into the curriculum may provide students with the opportunity to explore the imaginative dimension of all subject areas and develop their inherent imaginative capabilities. However, not just any approach to teaching philosophy will foster the intelligent imagination. Philosophy can be, and often is, taught in a didactic, teacher-centered way. Although Dewey's ideas about curriculum and pedagogy state that students should engage in reflective, communal inquiry, Dewey himself did not consider the benefits of teaching philosophy in schools. This is why Martha Nussbaum argues that Dewey's ideas about teaching Socratic critical thinking "are in need of supplementation" (2010, p. 73). She also identifies Lipman's Philosophy for Children method as a practical framework for teachers wanting to foster philosophical thinking (2010, p. 73). P4C uses fictional narratives rather than textbooks to actively engage students in philosophical inquiry. It is also heavily influenced by Dewey's ideas and is specifically designed to facilitate the creation of Deweyan-style communities of inquiry (Lipman, 2008; Cam, 2008; Bleazby, 2011). As such, Philosophy for Children is well designed to foster the intelligent imagination in schools.

\section{Fostering the Imagination through Philosophy for Children}

Since the aim of a Philosophy for Children class is to meaningfully reconstruct philosophically puzzling experiences, imaginative thinking is of fundamental importance. While children may have a natural propensity for imaginativeness, their 
thinking may also be more fanciful than imaginative at times. Students need to be scaffolded to develop the capacity for imagining possibilities and creating ideas that have the potential to be realized. This means that students must learn that even the imagination is governed by logic (Sigurdardóttir, 2002, p. 38). An idea or method that assumes that $1+1=3$ or "if $A$ then $B$, not $A$, therefore not $B$ " is unlikely to be effective at meaningfully reconstructing experience. Since $\mathrm{P} 4 \mathrm{C}$ is specifically aimed at facilitating reasonableness and incorporates the philosophical subdiscipline of logic, it is well equipped to help children create ideas that are imaginative rather than just fanciful. In the $\mathrm{P} 4 \mathrm{C}$ classroom, children are encouraged, through teacher questioning and specially designed activities, to seek and give reasons for ideas, search for evidence, consider alternatives, construct criteria to evaluate ideas, consider the implications of different ideas, look for examples, construct analogies, make generalizations, and so on. Logic provides children with a language and the tools to discuss good and bad inferences.

The communal inquiry structure of the P4C classroom may also scaffold the intelligent imagination in that it encourages children to consider alternative perspectives. When our ideas are made problematic by the differing or critical views of others, we must look beyond what is familiar and search for alternative meanings. Furthermore, the corrective potential of others can help us avoid thinking that is unrealistic and fanciful as opposed to imaginative. This is why Brynhildur Sigurdardóttir states that "four eyes are better than two, and communication with other people-listening to different perspectives-seems to be the best way to avoid imagination's dead ends" (2002, p. 34). Imagining with others helps us imagine alternative possibilities and ideas that are more objective (in the Deweyan sense) because they take into account the needs and interests of others. This limits the possibility of students imagining and desiring ends that are unlikely to be successfully realized in a social environment. The communal nature of the P4C classroom may help facilitate the empathetic imagination, which can enable students to imagine socially reconstructive ideas.

Philosophy for Children also emphasizes fallibilism, self-correction, and open-mindedness. These attitudes and abilities all depend on the capacity for imagination. The greater one's capacity for imagination, the less likely one is to fear changes, difference, or problems. This is because imaginative people know that if a new experience or idea problematizes their beliefs, they will be able to respond by imaginatively creating new understandings. As such, imaginative people are less likely to feel despair or be defensive and dogmatic when their beliefs are challenged. Consequently, they are more likely to be open to alternative perspectives and new experiences and be more likely to self-correct. They are more likely to see problems and alternatives as opportunities for imaginatively recreating current beliefs and gaining new knowledge. This is suggested by Lipman's description of creative thinkers: "The merely critical thinker is somehow conservative, in the sense that he or she is not content until finding a belief that dispenses with thinking. On 
the other hand, the creative thinker is essentially sceptical and radical. Creative thinkers are never so happy as when they have been let loose, like bulls in china shops, to smash to smithereens the bric-a-brac of the world" (2003, p. 254). Thus, the open-minded, self-corrective and flexible thinking that $\mathrm{P} 4 \mathrm{C}$ aims to facilitate is essentially imaginative thinking.

Another one of P4C's fundamental goals is to facilitate autonomy or the capacity to think for oneself (Lipman, 2003; Splitter \& Sharp, 1995). Independent thinking and autonomy also involve the intelligent imagination, which enables individuals to imagine things differently from how other people perceive them, and to dominant social values and practices. It is also through the intelligent imagination that individuals transform and influence their social-cultural environment in accordance with their own ideals. Thus, without the imagination one would simply have to follow the crowd and accept the status quo, even if one found it oppressive or undesirable. For marginalized groups, including children and young people, the imagination may be particularly important. Their interests and experiences may be those least reflected in dominant values and knowledge. The imagination enables young people to create and express ideas that are not entirely constrained by adult understandings. The intelligent imagination also enables us to transform ourselves in accordance with our personal goals or ideals. By helping students imagine reasonable ideas and possibilities, $\mathrm{P} 4 \mathrm{C}$ can help students set realistic and attainable goals for themselves and construct effective means for attaining them. As Degenhardt and McKay explain, a lack of autonomy often results from individuals setting goals that are unrealistic or ill conceived:

In envisaging future developments in our lives, in trying to foresee chosen activities and commitments, it is easy to focus on and exaggerate the rewards of a particular life-style. We may then become disillusioned and even bitter when we encounter the realities of such a life-style and our own aptitude for participating in it. This could have been avoided if our initial imaginings had been fuller, more disciplined, and better informed. (1988, p. 253)

\section{Conclusion}

In conclusion, the teaching of philosophy in schools, especially in accordance with the Philosophy for Children pedagogy and curriculum, can enable schools to foster Dewey's fruitful notion of intelligent imagination. This is because philosophy and Philosophy for Children emphasize the problematic, idealism, community, reasonableness, autonomy, open-mindedness, fallibilism, and the search for meaningfulness. This contrasts with traditional schooling which reflects Plato's concern that the imagination may lead us away from truth, understanding, and happiness. Traditional schools discourage the imagination by focusing on the accumulation of "acts" and the mastery of basic skills. If, as Dewey states, the aim and the means 
of education are growth, without the capacity for intelligent imagination, which is the ability to meaningfully transform oneself and one's world, one could not be educated. This is why Greene states that "a kindred imaginative ability is required if the becoming different that learning involves is actually to take place" (1995, p. 22). As such, the teaching of philosophy through engaging students in philosophical communities of inquiry should be central to all learning.

\section{References}

Apple, M. (2009). Controlling the work of teachers. In D.J. Flinders \& S. Thornton (Eds.), The curriculum studies reader (pp. 199-213). London: Routledge.

Barrow, R. (1988). Some observations on the concept of imagination. In K. Egan \& D. Nadaner (Eds.), Imagination and education (pp. 79-90). New York: Teachers College Press.

Berliner, D. C. (2009). MCLB (Much curriculum left behind): A U.S. calamity in the making, The educational forum, 73(4), 284-296.

Buenaseda-Saludo, M. (2003). Cultivating social imagination in the community of inquiry. Thinking: The journal of philosophy for children, 16(3), 36-41.

Bleazby, J. (2011). Overcoming relativism and absolutism: Dewey's ideals of truth and meaning in Philosophy for Children, Educational philosophy and theory, 43(5), 453-466.

Bundy, M. W. (1922). Plato's view of the imagination. Studies in Philology, 19(4), 362-403.

Cam , P. (2008). Dewey, Lipman and the tradition of reflective education. In M. Taylor, H. Schreier, \& P. Ghiraldelli (Eds.), Pragmatism, education, and children (pp. 163-181). New York: Rodopi.

Deganhardt, M. \& McKay, E. (1988). Imagination and education for intercultural understanding. In K. Egan \& D. Nadaner (Eds.), Imagination and education (pp. 237-255). New York: Teachers College Press.

Dewey, John. (1938). Logic, The Theory of Inquiry. New York: Henry Holt.

-_- (1958a). Art as experience. New York: Capricorn Books.

-_- (1958b). Experience and nature. New York: Dover Publications.

_-_. (1967). Psychology. In J. A. Boydston (Ed.), John Dewey: The early works. Vol. 2. Carbondale: Southern Illinois University Press.

_-_. (1991). Affective thought. In J. A. Boydston (Ed.), John Dewey: The later works. Vol. 2. Carbondale: Southern Illinois University Press.

- - - (1997). How we think: A restatement of the relation of reflective thinking to the educative process. New York: Dover Publications.

-_- (2004a). Democracy and education. New York: Dover Publications.

-_- (2004b). Reconstruction in philosophy. New York: Dover Publications.

Egan, K. (2007). Imagination, past and present. In K. Egan, M Stout \& K. Takaya (Eds.), Teaching and learning outside the box (pp. 3-20). New York: Teachers College Press. 
Egan, K. \& Judson G. (2009). Values and imagination in teaching. Educational philosophy and theory, 41(2), 127-140.

Fesmire, S. (2003). John Dewey and moral imagination: Pragmatism in ethics. Bloomington, IN: Indiana University Press.

Gilligan, C. (1982). In a different voice. Cambridge: Harvard University Press.

Glover, J. (1999). Humanity: A moral history of the twentieth century. London: Jonathan Cape.

Greene, M. (1995). Releasing the imagination: Essays on education, the arts and social change. San Francisco: Jossey-Bass Publishers.

Haralambous, B., Fitzgerald, R., \& Nielsen, T. (2007). You are now leaving Flatland: Why we need imagination in education. Professional Educator, 6(4), 38-41.

Hirsch, E. D. (1987). Cultural literacy: What every American needs to know. New York: Vintage Books.

Hamrick, W. S. (1989). Philosophy for Children and aesthetic education. Journal of aesthetic education, 23(2), 55-67.

Jo, S-H. (2002). Imagination in community of inquiry. Thinking: The journal of philosophy for children, 16(2), 39-43.

Johnson, M. (1993). Moral Imagination, implications of cognitive science for ethics. Chicago: University of Chicago Press.

Johnson. M. (2007). The meaning of the body: aesthetics of human understanding. Chicago: University of Chicago Press.

Kelly, A. V. (2009). The Curriculum: Theory and Practice (6th. ed.). London: Sage.

Kennedy, D. (2006). John Dewey on children, childhood and education. Childhood \& philosophy, 2(4). Retrieved 2010 from www.filoeduc.org/childphilo/n4/ dewey.html.

Kirkman, R. (2009). Teaching for moral imagination: Assessment of a course in environmental ethics. Teaching philosophy, 31(4), 333-350.

Lamb W. W. H. (2002). Philosophy for children and the philosophy of childhood. Every child, 8(4), 8-9.

Lingard, B. (2009, November). Testing times: The need for new intelligent accountabilities for schooling. Queensland teachers union professional magazine, pp. 13-19.

Lipman, M. (2003). Thinking in education. Cambridge: Cambridge University Press. _-_- (2008). Philosophy for Children's debt to Dewey. In M. Taylor, H. Schreier, \& P. Ghiraldelli (Eds.), Pragmatism, education, and children (pp. 143-151). New York: Rodopi.

Matthews, G. B. (1980). Philosophy and the young child. Cambridge, Massachusetts: Harvard University Press.

McNeil, John D. (2009). Contemporary curriculum: In thought and action (pp. 5369).Hoboken, NJ: John Wiley \& Sons.

Nussbaum, M. (2010). Not for Profit: Why democracy needs the humanities. Princeton: Princeton University Press 
Parfit, D. (1984). Reasons and persons. Oxford: Clarendon Press.

Plato. (1998). The republic. (R. Waterfield, Trans.). Oxford: Oxford University Press. Quirk, B. (2005). The anti-content mindset: The root cause of the "math wars." Retrieved 2011 from http://www.wgquirk.com/content.html.

Sigurdardóttir, B. (2002). Imagination. Thinking: The journal of philosophy for children, 16(2), 34-38.

Thayer, H. S. (1977). Plato on the morality of imagination. Review of metaphysics, 30(4), 594-618.

Vygotsky, Lev. (1978). Mind \& society. Cambridge: Harvard University Press.

Williams, B. (1973). A critique of utilitarianism. In J. C. Smart \& B. Williams (Eds.), Utilitarianism: For and against. Cambridge: Cambridge University Press.

Jennifer B. Bleazby is a lecturer in the Faculty of Education at Monash University.

E-mail: jennifer.bleazby@monash.edu 